\title{
FOREWORD
}

\section{Publishing and Library Support for Africa: an Update ${ }^{1}$}

\section{Carol Priestley}

Assistance to book and library development in African countries can take many forms. It ranges over a scale from support to local publishing ventures through loans for textbook procurement to donation of specialist journals and books to libraries. Today, assistance for indigenous publishing is being given higher priority chiefly because of the recognition that an appropriate and sustainable supply of books within Africa can only be provided by a viable African publishing industry. This is particularly true where publishing in local languages is concerned, but it is becoming increasingly clear that the needs of African readers for books in English, French and other international languages can be most effectively met by African publishers. Procurement from external sources is neither sustainable nor affordable in the long-term even if this were a desirable method of supplying books and journals to these markets. However, there is also a recognition that specialist and university libraries must remain part of the international world of scholarship and that assistance via purchase, exchange or donation of material remains important.

\section{Publishing}

Over the years the pattern of support to the supply of books has swung from large capital investments which are used to provide African countries with the textbooks they require to initiatives to help publishers in African countries to produce materials locally.

It is difficult to support publishing in African countries without running into the problems of the high costs of production and the lack of purchasing power of either governments or individuals. Though labour may be cheaper in developing countries, most equipment and materials for production have to be imported. Twenty to thirty years ago, with expansion then taking place in most educational systems in Africa, new textbooks were needed in large numbers. Textbooks dominated publishing and were a lucrative business (Per Gedin, 1991) attractive to private enterprise; indeed in anglophone countries in Africa textbooks accounted for 80-95 per cent of the total book market. Multinational publishing houses realised the potential of the market and many set up offices in African countries specifically to supply the textbook needs of each country, so squeezing out many indigenous publishers. With the recession, and profits on this scale no longer obtainable, the multinationals have closed or indigenised their local offices. For a few more years textbooks no longer needed in the North, particularly where changes of curriculum and GCSE examinations had rendered some of them 
out-of-date, were sold or even occasionally given free to various African countries, though their relevance to the recipients' school curricula was always doubtful. This has added to the pressure to create a viable publishing industry within these countries, and several agencies have been keen to support this development.

Early initiatives to support local publishing were often sporadic and uncoordinated: some focused on donation of paper or equipment (the latter sometimes without adequate provision for spare parts or maintenance), others on training potential writers or publishing staff in editing, marketing, etc. through workshops and seminars held in various African locations. From the 60 s to the late 80 s there were few examples of collaboration among donors. Some donors supported curriculum design, others production, others distribution. Some supported different aspects of publishing in different countries with no apparent logic behind the components of their programmes. Since then, the World Bank and bilateral donors, including the UK's Overseas Development Administration (ODA), have been seeking a comprehensive approach which would lead to the establishment of a well-functioning book provision system. A recent study of book and publishing assistance programmes (Priestley, 1992) approached 133 organisations - government, private, commercial - and identified fifty-nine, ranging from small charities to the World Bank and UNESCO, which are active in Africa. The conclusion from the information provided is that:

however much individual merit one-off projects may claim, their impact is short-lived and very local; and the need for a policy and planning framework is not yet well understood. This has been recognised by some donors and recipients in the past 5-7 years, but systematic definition and monitoring of the components of the publishing process in each African country have still to be explored.

To publish locally and successfully in Africa, three areas might be highlighted, all interdependent:

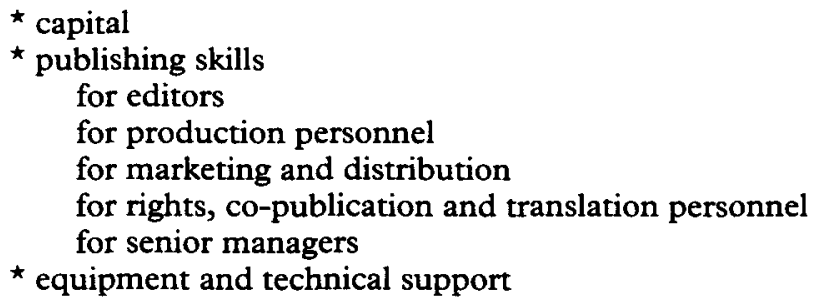

Examples of initiatives aimed at alleviating the problems in these areas can be found:

\section{1 capital}

Publishing is perceived to be a high-risk, low profit business and many would-be developing country publishers find it difficult if not impossible to raise the necessary capital to launch their business. Finance is of course particularly acute for the small publishers whose capital is locked up in projects and for whom a book may take up to two years from the time of commissioning to the finalised copy, and then takes an even longer time to sell.

The lack of capital outlay generally discourages the growth and development of the publishing industry, restricts the number of titles that can be published in any 
period and renders small scale publishing a very expensive business.

The devaluation of currencies has badly affected an already ailing industry which relies heavily on import of paper, ink, and printing machines. The problems are compounded by high import duties and taxes.

An alternative concept has been developed by the Dag Hammarskjold Foundation, Uppsala. The basic element of the programme is to provide guarantee of repayment to banks and lending agencies so that African publishers can borrow the funds they need. The Foundation offers professional advice if needed but instead of funding specific requirements they guarantee loans which are taken in commercial banks in a normal way. Kenya was chosen as a pilot country as it had a fairly well developed book market, though dominated by multinational publishers.

To guarantee the loans, a certain capital was needed to cover losses and bank expenses. A sum of US $\$ 300,000$ was deemed to be sufficient and the Dag Hammarskjold Foundation was successful in obtaining these funds from the Ford Foundation. The Hammarskjold Foundation wanted to create a normal situation between the bank and the publisher and wanted to emphasise that there was no donor dependency. They also wanted to show that the publisher was as reliable as any other business and that with adequate finance publishing could be a profitable industry.

\section{2 publishing skills}

Many of the failings of African publishing can be traced to a lack of appreciation of the importance of publishing skills. A 1985 report on textbooks prepared for the World Bank by Barbara Searle highlighted shortcomings - slow production schedules, inadequate paper procurement, teacher training out of phase with book publication, no coordination between curriculum and manuscript development and, above all, a failure to establish institutions that could continue to provide good quality books after project completion. The Bank has now realised that book publishing development cannot take place in isolation. The unknown factor in all aspects of training is of course the probable increase in the use of desk top publishing which will undoubtedly alter the future training needs of all the participants within the publishing field.

\section{a) for editors}

Examples of assistance to editorial teams are few and far between. But within the Faculty of Information Sciences at Moi University in Kenya a series of courses have been run with ODA support, aimed at covering all aspects of publishing, and including senior editorial managers. With the advent of desk top publishing, which will surely follow the pattern in the North where its use is more and more prevalent, the role of editors will change and become more powerful.

b) for production personnel

Again very few examples of training assistance for production personnel are to be found. Some of the help has come from UNESCO, the DSE and the IDRC. The DSE has supplied funds for two- or three-week workshops since 1980, using both expatriate and national teachers. These have been evaluated very highly, as have short courses supported by the UK's ODA.

\section{c) for marketing and distribution}

Often the weakest links in the chain in African publishing, most small indigenous publishers cannot afford publicity for their books and, until recently, joint lists or catalogues were an anathema. Even today, many publishers do not take advantage of existing opportunities for free international promotion of their books through 
such publications as African Book Publishing Record and the cumulative African Books in Print (both published by Hans Zell Publishers, Oxford). The book trade is undeveloped, as are attitudes to books and reading. One successful initiative is the Zimbabwe Book Marketing Scheme (ZBMS) which has three aims:

to encourage not only the book reading habit but also the habit of buying and owning books

to support indigenous publishers

to accelerate the emergence of a regional book market in southern Africa and develop pan-African book trading.

To date, ZBMS has attracted support from the Swedish International Development Authority (SIDA), the Zimbabwe Trust and CODE (the Canadian Organization for Development through Education). The scheme is now $63 \%$ self-sufficient. ZBMS is now exporting books from Zimbabwe to twenty countries, with substantial benefits to Zimbabwean publishers.

The main initiative for international distribution of African books has been the African Books Collective (ABC) ${ }^{2}$ (see Jay, 1993), started in Oxford, UK under the aegis of Hans Zell, as a cooperative by eleven African publishers in 1985 . ABC now serves forty-two African publishers, holds over 1200 titles in stock and sells throughout Europe and North America. For many of the publishers ABC has offered the first opportunity for them to have access to markets outside Africa and therefore to earn foreign exchange. Funding for the initial years of ABC's trading has been provided by Ford and Rockefeller Foundations, the Norwegian Agency for Development Cooperation (NORAD), SIDA, UNESCO and the Swedish Agency for Research Co-operation with Developing Countries (SAREC). Although ABC has made dramatic progress (from sales of $£ 84,000$ in 1991 to an estimated total income of $f 184,000$ in 1994), it could not have taken off without financial support from donors.

d) for rights, co-publication, etc

Publishing skills are not acquired overnight and the consistent lack of a secure financial base has often destroyed whatever skill was available or prevented its development. The role of licensing or sub-licensing, i.e. acquiring rights to reproduce titles published elsewhere under a royalty agreement, offers a short to medium term solution. Indigenous publishers often need help to seize a potential opportunity to co-publish a book important to their own area, but which they have not managed to secure for the international market as the originating publisher. Such arrangements often depend, however, on mutual collaboration with the publishers from the North as few indigenous publishers have access to hard currency to enable them to pay the originating publisher. However, recent initiatives such as the APNET (African Publishers Network) workshop on African rights (see below) are working towards a better understanding of the possibilities.

e) for senior managers

Publishing is by its very nature an entrepreneurial activity and it has to be recognised that the context within which publishers work varies between and within countries and regions. The investment required for publishing is quite substantial and capital outlay is only recouped over a long period. Financial management and business planning are skill areas which have received less attention than they deserve.

\section{3 equipment and technical support}

a) desk top publishing (DTP)

If there is to be development of desk top publishing (DTP), following the pattern 
of the increasing use of computer-based book production in the North with the consequence of greater use of camera ready copy (CRC), then there will be new and different requirements for training and equipment for the new technology. Many of the techniques and equipment donated and passed on to African countries in the 1980s and earlier will become redundant. The potential for DTP in some sectors is significant, not least the possibility of transmitting text by E-mail and thus generating CRC from text produced elsewhere.

b) paper

Shortage of paper is one of the most frequent problems encountered in publishing in Africa. Canada and Sweden have been the principal sources of paper support programmes - the former through CODE and the latter through SIDA. CODE estimates that about 450 tonnes of paper, costing in excess of US $\$ 2 \mathrm{~m}$ have been shipped to Africa since 1988. Finland and the former Soviet Union have also made paper available for specific publishing support projects.

Experience with the donation of paper has highlighted two pitfalls. The first is the difficulty of monitoring and controlling the allocation. Widespread misappropriation is not unknown. The second is that donation of paper to one publisher places others at a disadvantage. Subsidised publishers become dependent on free paper and when the donation comes to an end, so does the publishing programme.

To counteract the second of these problems, publishers are increasingly being asked to treat paper as a form of capital, tied to performance objectives. It has also been suggested that there should be a sliding scale of payment, according to the degree of need. In a struggling industry such as that of Burkina Faso, a local publisher might be asked to pay $10 \%$ of the value of the paper, while a Kenyan publisher might be asked to pay $75 \%$. These funds would be used for purchasing the books consequent on the subsidy and distributing them to local libraries. CODE's practice is to recommend distribution of these books in rural areas, so that the publishers' commercial market in the cities is not undermined.

As stated earlier some donors have provided printing and binding equipment, or even the machinery for manufacturing paper. But without sufficient technical support and help with obtaining spare parts, problems can rapidly develop.

Each of the donor agencies involved in supporting local publishing has its own agenda. Although much has been written about donor coordination and cooperation, it is not easy to implement. Over the past few years, meetings among donors, notably the Bellagio Group (see below), have led to some joint funding and the sharing of information. Sometimes donors have met at the invitation of the potential recipient, but most donor/recipient dialogue takes place on a bilateral basis.

The long-term goal is self-sustainable indigenous publishing. A book market with a functioning infrastructure from writer to publisher to distributor to reader will not be created by a flood of donated material or by multinational publishers. Practitioners (writers, publishers, booksellers and librarians) must work together with development agencies and donors. There is no single solution, but rather many component solutions within a coordinated strategy. This makes it difficult to construct a list of priorities for donors, most of whom, within their terms of reference, have to opt for a particular facet of support. When there is an adequate market, publishing and publishing skills develop naturally. If money is made available for book purchase, books will flow. One of the central roles for donor agencies should therefore be to assist books to flow from indigenous publishers.

On this criterion, the Africa Books Collective (ABC) and the Zimbabwe Book 
Marketing Scheme are two initiatives which can claim to maximise the effectiveness of donor support. Both of them could benefit from more regional funding.

One of the urgent needs is for bookbuyers in Africa to know what is available from other African countries. Many orders for African-produced books from other African countries pass through $\mathrm{ABC}$ in Oxford. Although a very large proportion of African publishers fail to use the available promotional services, still fewer librarians receive whatever book lists and publishers' catalogues are available. The importance of intraAfrican trade cannot be underestimated. The International African Institute (IAI) has received funding to establish an African Journals Distribution Programme (AJDP) ${ }^{3}$ A pilot phase is providing current subscriptions to eighteen academic journals from eleven African countries to twenty university libraries in ten countries. The IntraAfrican Book Support Scheme (IABSS) ${ }^{4}$, launched in 1991 was set up to ensure that books from the 42 publishers within the African Books Collective could reach the shelves of twelve major academic libraries in Africa.

\section{Information sharing on the book and publishing industry}

Many of the programmes presently available in support of indigenous publishing and library development are not achieving full potential. From the recipient's perspective it has not been easy to find out how professional partnerships and information exchange can be initiated, from the donor's point of view it has been difficult to keep informed of new initiatives. There is, however, a considerable amount of information available about library and book development on a local, regional and country/national basis, and there is even more information on bilateral, multilateral and NGO support and the potential for increasing such information sharing through the use of E-mail and other forms of networking is limitless. Recently, four networks have emerged to facilitate better sharing of information.

Firstly, the African Publishers Network (APNET) ${ }^{5}$ is a pan-African network of publishers and national publishers' associations which works to support and promote indigenous publishing throughout Africa. Established in February 1992, APNET's founder members resolved that publishing in Africa would develop substantially through intra-African cooperation. Its objectives are based on the need to work across national and linguistic boundaries; the coordination and maximum utilisation of existing African training resources; and intra-African trade and collaboration between publishers and international agencies. APNET has evolved through a series of practical tasks - the first being a survey of publishing training in Africa which both gave a broad survey of existing possibilities and laid the foundation for future investment. There are now two APNET training coordinators in place: one for East Africa based in Nairobi and one for West Africa based in Togo. APNET is organising or supporting national and regional workshops to strengthen and update publishing skills throughout the continent. Further it has a bi-monthly journal the African Publishing Review which is distributed to over 1200 African publishers and interested organisations. This has become an invaluable medium for news, debate and information sharing. Trade in books, printing and licensing agreements are promoted through a multi-faceted programme, including publication annually of $A$ frican Rights. In August 1994, APNET jointly organised a workshop with the Zimbabwe International Book Fair as a trade promotion and training exercise in rights. APNET also undertakes research and policy studies in key areas of publishing and book development.

Secondly, the Bellagio Publishing Network ${ }^{6}$ is an informal association of organisations dedicated to the strengthening of African publishing. The group includes 
donor organisations and NGOs concerned with publishing and book development, and has provided a useful forum for discussion. The network maintains a Secretariat in Oxford which holds responsibility for organising meetings of the group and maintaining communications between donors and potential participants and a Research and Information Centre in Boston, which holds responsibility for the quarterly publication of the network newsletter, development of a research agenda focusing on problems of publishing in the Third World and commissioning and publishing research reports on specific issues.

Thirdly the Donors to African Education (DAE) ${ }^{7}$, a consortium of multilateral, bilateral and non-governmental donors and African ministries of education and development bodies, has specific working groups on textbooks and libraries and on higher education. Although the early work of the 'Books' Working Group focused on the preparation and discussion of book sector studies, the group is now working closely with APNET to involve and support African educational publishers to enable them to take a central role in book provision.

The International Network for the Availability of Scientific Publications (INASP) ${ }^{8}$, is a cooperative network of interested organisations and libraries from the North and the South. It has three immediate objectives, namely to support and strengthen existing programmes involved in the publication, distribution, exchange and donation of books, journals and related materials; to encourage new initiatives that will increase the availability of quality scientific literature; and to identify methods that will permit the ongoing and sustainable publication, exchange and distribution of scientific publications. The Network has created several computerised databases, including one which provides current information on existing programmes of support and activity in the provision of scientific material and another which provides inventories and profiles of institutions and libraries in the South. The Network also offers a clearinghouse and advisory service and assists in the development and establishment of new programmes or activities in the field. It can match donors to appropriate counterparts in developing countries and vice versa. Inter-regional projects to address the issues are being supported, for instance a health information network is being planned: in Africa this will bring together members of the Association for Health Information and Libraries in Africa (AHILA) with the funding and health information supporting organisations.

\section{Library Support}

In the international world of scholarship and research, it is essential that academics in institutions in Africa are enabled to write and continue with their research with the books and journals they need available in their own institution libraries. Here the role of donors and donor agencies is somewhat different, though it may overlap in some instances with support for indigenous publishing as in the case of the African Journals Distribution Programme (AJDP) mentioned above.

The task of building strong academic centres and postgraduate and research programmes in particular cannot be accomplished without strengthening information services and the provision of teaching and learning materials. The ability of many university libraries to support teaching and research in their institutions is now highly questionable. In general, universities have not been able to allocate financial resources for the procurement of new books, to continue journal subscriptions, to modernise information management procedures through the utilisation of new technologies or to provide more reading space for increasing student numbers. 
Libraries, however, are one of the university facilities that are most resourcedependent and the deteriorating state of book and journal collections is a very evident result of dwindling university funds. What has kept African university libraries alive (if only barely) over the past five years is donor support. Donor programmes have stepped in to fill the gap in government funds. Without this, most might have collapsed completely. Support has been given in three main areas: materials (books and journals) purchase and donation; training, both long and short term; and acquisition of information technology (IT). A number of donors, international and bilateral, are involved; some concentrating on particular libraries or countries, others assisting throughout Africa. Support to university libraries appears to be popular with donors, perhaps because it can be easily specified, delivered and accounted for, for example the donation of a number of journal subscriptions.

It is now not unusual to find that, apart from the staff salaries, all inputs to a university library are provided by donors. However, coordination or even information sharing between donors is rare; for example, three or more donors may provide subscriptions to Western-published journals to the same university. Depending on which country is 'fashionable', aid may pour into one library, while another in a neighbouring country gets nothing.

All donor agencies now place much emphasis on aid leading to future sustainability. The relatively large amounts of support recently given to university libraries are aimed as a stop-gap measure to prevent further decline in collections and services during the period when university finances are put in order and plans for institutional effectiveness and efficiency are implemented. However, from the information available, the aid given to university libraries does not seem to be resulting in self-supporting libraries. There are many examples of the total cancellation of journal subscriptions once the outside funding ceases, of knowledge gained during training never being implemented, of IT systems proving too expensive to use and maintain, of plans for resource sharing being aborted before birth. And, of course, there is also a problem of security when resources are so scarce.

The recent profile of research libraries in sub-Saharan Africa undertaken by the American Association for the Advancement of Science (AAAS) (see Levey, 1993) gives details of thirty-one (mainly university) libraries. Of these, eight do not subscribe to any foreign periodicals with their own funds, and only twelve subscribe to over 100 journals. The University of Zimbabwe is shown to be the best endowed library and, although in receipt of donor assistance, most journal subscriptions (1578 out of 2699) are paid for with university funds. This is doubtless because the deans of relevant faculties have placed library needs first in allocating the university's foreign currency allowance. At the other end of the scale, the University of Nigeria, Nsukka, lacks both an acquisitions budget and donor support.

Some libraries have access to local currency which they can use to purchase UNESCO coupons, and in turn they can be used for the purchase of books, journals and other educational materials. The British Council and the World Health Organisation (WHO) also have programmes which utilise local currency payments. However, countries where such schemes operate are limited at present.

Of the book and journal donation programmes, those of SAREC and the AAAS are probably the most significant. The AAAS supplies up to 191 journal titles to 250 university and research libraries in 38 countries and is also now supplementing print journals with a small number of bibliographical and full text databases on compact disc. SAREC has substantial library support programmes in Eritrea, Ethiopia, Tanzania, Mozambique and Zimbabwe and for several years their programme has had three main 
components: supply of current journal subscriptions, library training and purchase of equipment. Each country is given an annual notional allocation, ranging from $\$ 150,000$ to $\$ 450,000$, and within this the libraries involved meet together to decide on their own priorities. The funds can be held within the country concerned, and local management and procurement is encouraged. Over the past 6 months discussions have been held with each participating partner, and possibilities for inter-library networking, alternative forms of document provision with the use of new technologies and electronic communication are being explored. Complementary to the provision of international scientific literature, SAREC have for some years also funded a small number of projects in support of indigenous publishing of scholarly journals.

The International Campus Book Link (ICBL) ${ }^{9}$ is a modest targeted programme aiming to provide a coordinated scheme of book and periodical donations from British universities, colleges and individuals to university libraries and departments in Africa. It is hoped that the system of linking universities in the UK to counterparts in Africa will provide not only materials but also a communications link between faculties and academics which in turn can be the start of sustainable longer-term cooperation.

The application of new information technologies offers many opportunities and challenges to African university libraries. Twenty-one libraries are known to have CD-ROM capability and despite problems in installing and maintaining their systems there are some interesting success stories. The Medical Library at the University of Zimbabwe actively promotes its CD-ROM services to health and medical workers throughout the country. This has resulted in a dramatic growth in demand for CDROM literature searches - some 400 searches, for example, being undertaken in March 1993 alone. The Cheikh Anta Diop University, Dakar, Senegal, is a regional resource centre for seven francophone libraries and conducts literature searches for researchers in Côte d'Ivoire, Togo and Mali. The INFO-MED project at the Medical Library of the University of Zambia illustrates innovative use of new technologies. INFO-MED combines CD-ROM with electronic networking for lecturers, researchers and students in Lusaka as well as for practitioners and researchers throughout Zambia. Requests from outside Lusaka utilise the terrestrial telephone-based FIDONET E-mail network. Requests for full text literature are sent to the University of Florida Medical Library which has been twinned by SatelLife via a low earth orbit satellite. The University of Florida sends the documents on a monthly basis by mail.

Thus although for many African university libraries the current situation with regard to provision of information services remains bleak, it has been shown that where policy and decision makers have placed library services near the top of their list of priorities significant advances have been made. CD-ROM technology has provided improved access to information and current awareness. This in itself has increased the demand for information. Electronic networking and the use of electronic communications to access information held in the 'North' also hold immense potential.

\section{Conclusion}

Publishing has rarely received the attention it deserves, nor has there been a sufficient understanding that publishing is not just about production but also about consumption. Within the industry much may be possible, but unless the market develops, little will be achieved. Local publishers may encourage local authorship, original texts and much original thought, but the importance of a full understanding of market needs is important to ensure that resulting publications are viable. In many African countries an autonomous publishing industry has been thwarted from emergence. Too often and 
regrettably, book aid schemes have exacerbated the situation by flooding the market with free or very cheap books. The greatest challenge for the future will be to harness available donor funding and support in a way that will at the same time encourage new national and regional initiatives at a realistic and practical level. Resource sharing, sustainable collection development and new technology applications are high on the agenda of libraries and publishers throughout the world. The strengthening of publishing and libraries in Africa is essential for future development.

International African Institute London

\section{References}

Gedin, Per. 1991. 'British publishers' contribution to African literature', Logos, the professional journal of the book world, 2(3).

-1992. 'Cultural pride: the necessity of indigenous publishing', in Philip Altbach (ed.), Publishing and Development in the Third World. Oxford: Hans Zell, pp. 43-53.

Jay, Mary. 1993. 'The African Books Collective' Foreword in CH Allen (ed.) Africa Bibliography 1992, Edinburgh: Edinburgh University Press for the International African Institute, pp.vi-xviii

Levey, Lisbeth A. 1993. A Profile of Research Libraries in Sub-Saharan Africa: acquisition, outreach and infrastructure. Washington DC: American Association for the Advancement of Science.

Priestley, Carol. 1992. Book and Publishing Assistance Programs: a review and inventory. Boston, MA: Bellagio Network Research and Information Center.

-1993a. 'Learning Resources in Higher Education in Developing Countries: the present position of libraries and book development', paper presented to the EADI information and Documentation Working Group meeting in Berlin.

-1993b. 'The difficult art of book aid: an African survey', Logos, the professional journal of the book world 4(4): 215-21.

-1994. 'Availability of publications in Africa: exchange of experience and future prospects', FID Bulletin, June 1994.

\section{Notes}

1. Much of this foreword updates and reconsiders material published earlier, see Priestley 1992, 1993a, 1993b and 1994

2. ABC, African Books Collective, The Jam Factory, 27 Park End Street, Oxford OX1 1HU.

3. AJDP, International African Institute, SOAS, Thornhaugh Street, Russell Square, London WC1H 0XG.

4. IABSS, African Books Collective, The Jam Factory, 27 Park End Street, Oxford OX1 1HU.

5. APNET, 78 Kaguvi Street, Harare, Zimbabwe.

6. Bellagio Publishing Network, Oxford Secretariat, 27 Park End Street, Oxford OX1 1HU. Research and Information Center, c/o School of Education, Campion Hall, 226 Boston College, Chestnut Hill, MA 02167.

7. DAE Working Group on Textbooks and Libraries, c/o Carol Priestley, 
International African Institute, SOAS, Thornhaugh Street, Russell Square, London WC1H 0XG.

DAE Working Group on Higher Education, c/o William Saint, The World Bank, 1818 H Street NW, Washington, DC 20433.

8. INASP, PO Box 2564, London W5 1ZD.

9. ICBL is managed by Book Aid International, 39-41 Coldharbour Lane, Camberwell, London SE5 9NR. 